\title{
The Effect of Understanding Fixed Asset Management and Auditor Integrity towards the Quality of Audit report at Regional Inspectorate of Gorontalo Province
}

\author{
Yulnaningsih Paneo, Rosman Ilato, Abd Rahman Pakaya, Ismet Sulila \\ Program Studi Magister Ilmu Administrasi \\ Universitas Negeri Gorontalo 2020
}

\begin{abstract}
This research aims to find out The Effect of Understanding Fixed Asset Management and Auditor Integrity towards the Quality of Audit report at Regional Inspectorate of Gorontalo Province partially and simultaneously. Its approach is quantitative, while the method is expost facto. In addition, the research design is causality. The technique of data analysis is multiple regression. The findings reveal that (1) understanding fix asset management influences positively and significantly towards the quality of audit report at Regional Inspectorate of Gorontalo Province with an effect level of 62,60\%. The better the understanding of auditor on fixed asset management, the better the quality of audit report Regional Inspectorate of Gorontalo Province. (2) auditor integrity influences positively and significantly towards the quality of audit report at Regional Inspectorate of Gorontalo Province with an effect level of $66,10 \%$. The better the auditor integrity in running the tasks mandated to him/her, the better the quality of audit report at Regional Inspectorate of Gorontalo Province. (3) understanding fixed asset management and auditor integrity simultaneously influence positively and significantly towards dependent variable (the quality of audit report at Regional Inspectorate of Gorontalo Province has determination value of $72,00 \%$ while the rest $28,00 \%$ can be explained by other variables such as objectivity, audit time pressure, organizational commitment, work loyalty, dysfunctional behavior and technical guidance related to intense and routine investigation.
\end{abstract}

Keywords: Audit Report Quality, Understanding of Auditor, Auditor Integrity 


\section{PENDAHULUAN}

Laporan audit yang dihasilkan oleh auditor khususnya auditor internal pemerintah daerah khususnya di Provinsi Gorontalo sudah bagus dan sesuai dengan ketetapan yang berlaku, namun laporan tersebut kadangkala masih mendapatkan koreksi dimana beberapa aspek yang dianggap sudah baik oleh auditor ternyata masih menjadi temuan bagi pihak Badan Pemeriksa Keuangan (BPK) RI. Hal ini menunjukan bahwa belum maksimalnya kualitas laporan audit dari pemerintah khususnya Inspektorat yang ada di Provinsi Gorontalo. Hal ini didominasi oleh berbagai temuan yakni pada pengelolaan aset tetap pada pemerintah Provinsi Gorontalo. Terkait dengan kualitas audit yang dipengaruhi oleh pemahaman dalam pengelolaan aset tetap dan integritas auditor maka penelitian ini difokuskan pada Inspektorat sebagai badan pengawas dan pengendalian internal pemerintah.

Hasil audit BPK RI atas pemerintah di Provinsi Gorontalo pada dasarnya sudah baik namun masalah yang terjadi yakni pada 2 Kabupaten yakni Kabupaten Boalemo dan Gorontalo Utara yang belum mampu mempertahankan opini wajar tanpa pengecualian. Hal ini tentunya diperngaruhi oleh berbagai faktor salah satunya karena kurang maksimalnya dalam melakukan pemeriksaan oleh auditor. Kualitas audit yang dilaksanakan oleh aparat Inspektorat
Provinsi Gorontalo saat ini masih menjadi sorotan, karena masih adanya temuan audit yang tidak terdeteksi oleh aparat inspektorat sebagai auditor internal, akan tetapi ditemukan oleh auditor eksternal yaitu Badan Pemeriksa Keuangan (BPK). Terkait kualitas laporan keuangan Pemerintah masih terdapat berbagai kekurangan diantaranya masih terdapat berbagai tindakan korupsi yang dilakukan oleh pegawai padahal terdapat Inspektorat daerah sebagai pengawas dalam kegiatan Pemerintahan suatu daerah

Pemeriksaan yang dilakukan APIP terkadang menemui kendala bagaimana meningkatkan sikap atau perilaku, kemampuan aparat pengawasan dalam melaksanakan pemeriksaan, sehingga pengawasan yang dilaksanakan dapat berjalan secara wajar, efektif dan efisien (Sukriah, dkk 2009). Pratama (2016) mengungkapkan bahwa Pengelolaan aset daerah merupakan aspek penting dalam Pemerintah Daerah, namun belum banyak Pemerintah Daerah yang mampu mengelola aset-aset daerahnya dengan baik, hal ini dapat disebabkan oleh beberapa faktor meliputi kurangnya pemahaman terkait dengan manajemen aset daerah.

Selain dengan pendekatan pemahaman pengelolaan aset tetap, prinsipprinsip perilaku yang berlaku bagi auditor antara lain integritas. Integritas diperlukan agar auditor dapat bertindak jujur dan tegas dalam melaksanakan audit (Sukriah, dkk 
2009). Pengaruh integritas terhadap kualitas audit sebagaimana dikatakan oleh Agoes (2012: 279) bahwa integritas merupakan kualitas yang menjadikan timbulnya kepercayaan masyarakat dan tatanan nilai tertinggi bagi anggota profesi dalam menguji semua keputusannya yang mengharuskan auditor dalam berbagai hal untuk jujur dan terus terang dalam batasan kerahasiaan objek pemeriksaan.

Permasalahan mengenai pemahaman PSAP yakni masih kurangnya pemahaman dari auditor dalam hal penerapan Pernyataan Standar Akuntansi Pemerintahan. Sebab apabila auditor mampu untuk memahami secar menyeluruh, maka auditor akan mampu melakukan deteksi mengenai ketidakwajaran pelaporan keuangan. Hal ini terutama terjadi pada Inspektorat Kabupaten Gorontalo Utara dan Kabupaten Boalemo yang seharusnya mampu mendeteksi sejak dini kesalahan/ penyimpangan maupun ketidaksengajaan dalam penyajian laporan keuangan. Namun kenyataannya hal ini nanti ditemukan oleh BPK RI Perwakilan Provinsi Gorontalo. Selanjutnya terkait dengan pemahaman yakni berdasarkan wawancara yakni para pegawai masih kurang baik dan teliti dalam melakukan audit serta masih kurang disiplinnya pegawai sehingga kompetensinya (pemahaman) masih kurang baik. Pehamanan pegawia inspektorat masih kurang optimal pada aset-aset pemerintah daerah, hal tersebut tercermin dari beberapa bukti hasil LKPD yang mana temuan yang paling banyak itu yakni pada aspek aset. Sehingga penting bagi pegawai dalam meningkatkan pemahaman Pernyataan Standar Akuntansi Pemerintahan terutama terkait dengan aset tetap pemerintah.

Kemudian dari segi intergritas bahwa auditor Inspektorat Provinsi Gorontalo telah memiliki sikap berani, jujur dan sikap positif lainnya namun belum mampu memberikan dampak yang signifikan bagi tercapainya hasil kerja yang lebih optimal dan terjadi peningkatan hasil capaian setiap tahunnya. Dengan adanya peningkatan kemampuan emosional dan spiritual akan membuat integritas. Sehingga untuk mencapai integritas yang baik perlunya perhatian dari berbagai pihak untuk meningkatkan aspek emosional dan spiritual dari auditor dalam melakukan pemeriksaan dan tanggung jawab lainnya.

Adanya permasalahan di atas merupakan fenomena menarik untuk diteliti secara ilmiah. Maka dari itu, peneliti tertarik untuk melakukan sebuah penelitian ilmiah dengan judul "Pengaruh Pemahaman Pengelolaan Aset Tetap dan Integritas Auditor terhadap Kualitas Laporan Audit di Inspektorat Daerah Provinsi Gorontalo".

\section{METODOLOGI PENELITIAN}

Penelitian ini akan dilaksanakan di Inspektorat Daerah Provinsi Gorontalo 
dengan objek penelitiannya adalah para karyawan dan data laporan audit Inspektorat Daerah Provinsi Gorontalo. Waktu penelitian direncanakan selama 4 (empat) bulan yaitu mulai dari Desember 2019 sampai dengan selesai April 2020. Definisi konseptual dan operasional untuk masing-masing variabel sebagai berikut:

\section{Tabel 1: Definisi Operasional Variabel}

\begin{tabular}{|c|c|c|}
\hline Variabel & Indikator & Skala \\
\hline $\begin{array}{c}\text { Kualitas } \\
\text { Laporan } \\
\text { Audit } \\
\text { (Y) }\end{array}$ & $\begin{array}{ll}\text { 1. } & \text { Pengelolaan Fungsi Audit } \\
\text { Internal } \\
\text { 2. Lingkup Penugasan } \\
\text { 3. Perencanaan Penugasan } \\
\text { 4. Pelaksanaan Penugasan } \\
\text { 5. Komunikasi Hasil Penugasan } \\
\text { 6. Pemantauan Tindak Lanjut } \\
\text { (Tugiman, 2006:53) }\end{array}$ & Ordinal \\
\hline $\begin{array}{c}\text { Pemahaman } \\
\text { atas } \\
\text { pengelolaan } \\
\text { aset tetap }\end{array}$ & $\begin{array}{l}\text { 1. Pengakuan Asset } \\
\text { 2. Pengukuran/Penilaian Asset } \\
\text { 3. Pengeluaran Setelah Perolehan } \\
\text { (Subsquent Expenditure) } \\
\text { 4. Penyusutan Asset } \\
\text { 5. Penghentian dan Pelepasan } \\
\text { Asset } \\
\text { 6. Pengungkapan Asset } \\
\text { (Nikijuluw, dkk (2017: 45) }\end{array}$ & Ordinal \\
\hline $\begin{array}{c}\text { Integritas } \\
\text { Auditor }\end{array}$ & $\begin{array}{l}\text { 1. } \quad \text { Kejujuran auditor } \\
\text { 2. } \quad \text { Keberanian auditor } \\
\text { 3. } \quad \text { Sikap bijaksana auditor } \\
\text { 4. } \quad \text { Tanggungjawab auditor } \\
\text { (Sukriah, 2009:30) }\end{array}$ & Ordinal \\
\hline
\end{tabular}

Populasi pada penelitian ini adalah 75 orang auditor dan pengawas Inspektorat. Dalam penelitian ini menggunakan sampel jenuh sehingga semua populasi menjadi sampel penelitian. Teknik analisis data yang digunakan dalam penelitian ini adalah regresi berganda. Bentuk persamaan dari regresi berganda adalah:

$$
Y=\alpha+\beta_{1} X_{1}+\beta_{2} X_{2}+\varepsilon
$$

Dimana:

$\mathrm{Y}=$ Laporan hasil audit

$\alpha=$ Konstanta, besar nilai $Y$ jika $X=0$

$\beta_{1}-\beta_{2}=$ Koefisien regresi

$\mathrm{X}_{1}, \mathrm{X}_{2}=$ Pemahaman pengelolaan aset tetap, Integritas Auditor Internal $\varepsilon=$ Error term

\section{HASIL PENELITIAN \\ 1. Statistik Deskriptif}

Hasil analisis deskriptif untuk setiap variabel dalam penelitian ini disajikan sebagai berikut:

Tabel 2: Hasil Analisis Deskriptif

\begin{tabular}{|c|c|c|c|c|}
\hline No & Deksriptif & $\begin{array}{c}\text { Pemahaman } \\
\text { Auditor }\end{array}$ & $\begin{array}{c}\text { Integritas } \\
\text { Auditor }\end{array}$ & $\begin{array}{c}\text { Kualitas } \\
\text { Lap. } \\
\text { Audit }\end{array}$ \\
\hline 1 & Min & 84.00 & 75.00 & 79.00 \\
\hline 2 & Max & 122.00 & 120.00 & 125.00 \\
\hline 3 & Mean & 102.03 & 100.48 & 100.35 \\
\hline 4 & Std Dev & 10.12 & 11.45 & 10.49 \\
\hline 5 & $\begin{array}{c}\text { \% Skor } \\
\text { Variabel }\end{array}$ & $81.62 \%$ & $80.38 \%$ & $80.28 \%$ \\
\hline 6 & Kriteria Skor & Paham & Berintegritas & Berkualitas \\
\hline
\end{tabular}

Sumber: Pengolahan Data Excel, 2020

Berdasarkan tabel di atas maka dapat dijabarkan hasil deskriptif berikut ini:

\section{a. Variabel Pemahaman pengelolaan aset tetap}

Skor variabel Pemahaman

pengelolaan aset tetap yakni sebesar sebesar $81,62 \%$ yang berada pada kategori yang "paham". Hal ini menunjukan bahwa auditor di Inspektorat Daerah Provinsi Gorontalo memiliki tingkat pengetahuan dan pemahaman terkait dengan pengelolaan aset tetap yang sesuai dengan pernyataan standar akuntansi pemerintahan (PSAP) sehingga auditor dapat melakukan deterksi kesalahan aatu ketidakwajaran dalam pengelolaan aset yang harus dibenahi oleh instansi lain di lingkungan Provinsi Gorontalo. Pemahaman yang semakin optimal harus terus dikembangkan oleh pemerintah melalui bimbingan teknis baik on the job maupun off the job kepada para auditor agar hasil laporan audit kedepannya makin berkualitas. 
b. Variabel Integritas auditor

Variabel Integritas auditor terletak pada kriteria yang berintegritas dengan persentase skor sebesar 80,38\%. Hal ini menunjukan bahwa auditor di Inspektorat Daerah Provinsi Gorontalo memiliki sikap yang baik dalam menjalankan tugas dan tanggung jawabnya sebagai pemeriksa dan pengawasan internal pemerintah di Provinsi Gorontalo. Integritas auditor harus terus ditingkatkan guna menyikapi berbagai fenomena dalam menjalankan amanah sebagai aparatur sipil negara yang bertugas sebagai auditor di lingkungan pemerintahan yang kerap kali menggoyahkan integritas.

\section{c. Variabel Kualitas laporan audit (Y)}

Variabel Kualitas laporan audit di Inspektorat Daerah Provinsi Gorontalo yakni sebesar $80,28 \%$ yang terletak pada kriteria yang berkualitas. Hal ini menunjukan bahwa auditor Inspektorat Daerah Provinsi Gorontalo mampu untuk menghasilkan audit yang berkualitas yang sesuai dengan tupoksi kerja sehingga pemerintah Provinsi Gorontalo mampu memperoleh opini Wajar Tanpa Pengecualian selama bebrapa tahun terakhir. Meski sudah baik namun auditor harus lebih meningkatkan kualitas laporan audit terutama rekomendasi positif mengenai lingkup penugasan.

\section{Hasil Analisis Data Regresi Berganda}

Hasil analisis data merupakan gambaran mengenai hasil pengujian hipotesis, persamaan regresi hingga koefisien determinasi. Hasil pengujiannya dapat disajikan berikut ini:

\section{Tabel 3: Hasil Analisis Regresi Berganda}

\begin{tabular}{|c|c|c|c|c|}
\hline \multirow{2}{*}{ No } & \multirow{2}{*}{ Jenis Uji } & Statistik & $\begin{array}{c}\text { Pemahaman } \\
\text { Auditor }\end{array}$ & $\begin{array}{c}\text { Integritas } \\
\text { Auditor }\end{array}$ \\
\hline \multirow{2}{*}{1} & \multirow{2}{*}{$\begin{array}{c}\text { Regresi } \\
\text { Berganda }\end{array}$} & Alpha $(\alpha)$ & \multicolumn{2}{|c|}{17.186} \\
\cline { 3 - 5 } & & Beta $(\beta)$ & 0.404 & 0.444 \\
\hline \multirow{2}{*}{2} & \multirow{2}{*}{ Uji t (Parsial) } & $\mathrm{t}_{\text {hitung }}$ & 4.181 & 5.176 \\
\cline { 3 - 5 } & & P-Value & 0.000 & 0.000 \\
\hline \multirow{2}{*}{3} & \multirow{2}{*}{ Uji F (Simultan) } & $\mathrm{F}_{\text {hitung }}$ & \multicolumn{3}{|c|}{95.983} \\
\cline { 3 - 5 } & & P-Value & \multicolumn{3}{|c|}{0.000} \\
\hline \multirow{2}{*}{4} & \multirow{2}{*}{$\begin{array}{c}\text { Koefisien } \\
\text { Determinasi }\end{array}$} & $\mathrm{R}^{2}$ & \multicolumn{3}{|c|}{0.727} \\
\cline { 3 - 5 } & Adj R $\mathrm{R}^{2}$ & \multicolumn{3}{|c|}{0.720} \\
\hline
\end{tabular}

Sumber: pengolahan Data, 2020

Berdasarkan tabel di atas maka dapat dijabarkan hasil pengujian hipotesis, persamaan regresi hingga koefisien determinasi:

\section{a. Persamaan Regresi Berganda}

Berdasarkan hasil analisis pada tabel 4.11, model regresi linear berganda yang bangun adalah:

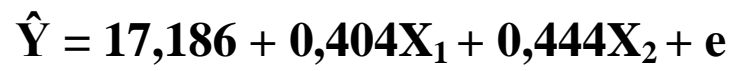

\section{b. Hasil Uji Parsial}

1) Pengaruh Pemahaman pengelolaan aset tetap Terhadap Kualitas laporan audit

Berdasarkan analisis diperoleh nilai $\mathrm{t}_{\text {hitung }}$ untuk variabel Pemahaman pengelolaan aset tetap sebesar 4,181. Jika dibandingkan dengan nilai $t_{\text {tabel }}$ yang sebesar 1,993. Maka $t_{\text {hitung }}$ yang diperoleh lebih besar dari nilai $t_{\text {tabel. }}$ Nilai signifikansi Pemahaman pengelolaan aset tetap lebih kecil dari nilai probabilitas 0,05 , atau nilai $(0,000<0,05)$, maka pemahaman pengelolaan aset tetap berpengaruh positif dan signifikan terhadap Kualitas laporan audit di Inspektorat Daerah Provinsi Gorontalo. 
2) Pengaruh Integritas auditor terhadap Kualitas laporan audit

Berdasarkan analisis diperoleh nilai $t_{\text {hitung }}$ untuk variabel Integritas auditor sebesar 5,176. Jika dibandingkan dengan nilai $t_{\text {tabel }}$ yang sebesar 1,993. Maka $t_{\text {hitung }}$ yang diperoleh lebih kecil dari nilai $t_{\text {tabel }}$. Nilai signifikansi Integritas auditor lebih besar dari nilai probabilitas 0,05 , atau nilai $(0,000<0,05)$, maka Integritas auditor berpengaruh positif dan signifikan terhadap Kualitas laporan audit di Inspektorat Daerah Provinsi Gorontalo.

\section{c. Hasil Pengujian Simultan (Uji F)}

Berdasarkan tebel 4.10 didapat nilai $F_{\text {hitung }}$ penelitian ini sebesar 95,983. $F_{\text {tabel }}$ pada tingkat signifikansi 5\% dan df1 sebesar $\mathrm{k}=2$ dan df 2 sebesar $\mathrm{N}-\mathrm{k}-1=75-2-1=72$ adalah sebesar 3,124. Jika kedua nilai $\mathrm{F}$ ini dibandingkan, maka nilai $\mathrm{F}_{\text {-hitung }}$ yang diperoleh jauh lebih besar $F_{\text {tabel }}$ sehingga Ho ditolak dan H1 diterima. Artinya variabel bebas (pemahaman pengelolaan aset tetap dan Integritas auditor) secara bersama-sama berpengaruh positif dan signifikan terhadap variabel terikat (Kualitas laporan audit di Inspektorat Daerah Provinsi Gorontalo).

\section{Koefisien Determinasi}

Nilai Adjusted $R$ Square sebesar 0,720. Nilai ini menunjukan bahwa sebesar $72,00 \%$ variabilitas kualitas laporan audit di Inspektorat Daerah Provinsi Gorontalo dapat dijelaskan oleh pemahaman pengelolaan aset tetap dan integritas auditor, sedangkan sisanya sebesar $28,00 \%$ dapat dijelaskan oleh variabel lain yang tidak diteliti dalam penelitian ini seperti variabel obyektivitas, tekanan waktu audit, komitmen organisasi, loyalitas kerja, perilaku disfungsional dan bimbingan teknis terkait dengan pemeriksaan yang intens dan rutin.

Selanjutnya dilakukan pengujian koefisien parsial. Hasil pengujain untuk koefsien determinasi parsial dijabarkan dalam tabel berikut ini:

Tabel 4.15: Koefisien Determinasi Parsial

\begin{tabular}{|c|c|c|c|}
\hline Model & \multirow{2}{*}{$\mathbf{R}$} & \multicolumn{2}{|c|}{ Determinasi } \\
\cline { 3 - 4 } & & $\mathbf{R}^{\mathbf{2}}$ & $\mathbf{\%}$ \\
\hline Pemahaman Pengelolaan Aset Tetap & 0.791 & 0,626 & $62,60 \%$ \\
\hline Integritas Auditor & 0.813 & 0,661 & $66,10 \%$ \\
\hline Sumber:
\end{tabular}

Sumber: Data Olahan SPSS 21, 2020

\section{PEMBAHASAN}

1. Pengaruh Pemahaman pengelolaan aset tetap terhadap Kualitas laporan audit di Inspektorat Daerah Provinsi Gorontalo

Pengelolaan aset dibutuhkan suatu pemahaman dari pelaksana pengelolaan maupun pemahaman dari pihak yang melakukan pengawasan. Selaku pihak yang melakukan pengawasan maka Inspektorat melalui auditor harus benar-benar paham mengenai seluk beluk mengenai aset atau barang milik daerah. Sebagaimana menurut Abdussamad (2014:95) bahwa pemahaman atau pengetahuan merupakan bagian dari suatu kompetensi yang nampak. Pemahaman dalam hal ini yakni pemahaman atas Pernyataan Standar Akuntansi Pemerintahan 
Nomor 7 yang memadai mencakup pengalaman dan pengetahuan dari auditor dalam melakukan pemeriksaan.

Pentingnya pemahaman auditor ditingkatkan guna meningkatkan kecermatan profesionalnya dalam pemeriksaan karena kecermatan profesional menjadi ciri khas dari seorang auditor untuk itu baiknya auditor terus berupaya untuk lebih teliti dalam bekerja dan harus memilih dan memilah sampel dan lingkup pemeriksaan yang sifatnya teknis dalam kewajaran pengelolaan keuangan dan aset daerah. Dalam hal ini audutor harus lebih fokus pada sesuatu yang memiliki nilai material tinggi kemudian setelah itu fokus pada kepatuhan sistem pengendalian intern pemerintahan. Hal ini sebagaimana menurut Manopo dalam Sulila (2018) dimana terdapat 2 pendekatan yang dapat dilakukan guna meningkatkan pemahaman atau dalam hal kompetensinya yakni peningkatan kompetensi dari nol dan pendekatan peningkatan kompetensi saat ini.

Hasil pengujian regresi khususnya untuk rumusan hipotesis pertama menunjukan bahwa nilai $t_{\text {hitung }}$ yang diperoleh lebih besar dari nilai $t_{\text {tabel}}$. Nilai signifikansi Pemahaman pengelolaan aset tetap lebih kecil dari nilai probabilitas 0,05, atau nilai $(0,000<0,05)$. Sehingga dengan demikian dapat disimpulkan bahwa pemahaman pengelolaan aset tetap berpengaruh positif dan signifikan terhadap Kualitas laporan audit di Inspektorat Daerah
Provinsi Gorontalo. Koefisien dari regresi untuk pengujian hipotesis pertama yakni positif. Nilai t positif menunjukkan bahwa adanya hubungan yang searah antara pemahaman pengelolaan aset tetap dengan kualitas laporan audit Inspektorat Daerah Provinsi Gorontalo. Artinya semakin baik pemahaman auditor atas pengelolaan aset tetap maka laporan audit Inspektorat Daerah Provinsi Gorontalo akan semakin berkualitas.

Pemahaman ataupun keahlian adalah auditor internal yang mempunyai pengalaman yang cukup untuk melakukan audit secara objektif, cermat dan seksama. Keahlian seorang auditor internal didalam menjalankan tugas profesionalismenya akan mempengaruhi tingkat kualitas audit yang baik, begitu juga sebaliknya bila keahlian rendah atau buruk maka kualitas audit yang dihasilkan rendah. Syamsuddin (2004) mengatakan bahwa keahlian sebagai keberadaan dari pengetahuan tentang suatu lingkungan tertentu, pemahaman terhadap masalah yang timbul dalam lingkungan tersebut, dan keterampilan untuk memecahkan masalah tersebut. Auditor dapat mencapai keahlian melalui pendidikan formal dan praktik audit, selain itu auditor harus menjalani pelatihan teknis maupun pendidikan umum.

Hasil penelitian yang menemukan terdapat pengaruh pemahaman pengelolaan aset tetap terhadap Kualitas laporan audit di 
Inspektorat Daerah Provinsi Gorontalo sejalan dan mendukung penelitian yang pernah dilakukan oleh Sari dkk (2014) bahwa pemahaman merupakan kemampuan dari SDM untuk menggunakan sebuah sistem atau aturan dengan baik. Sumber daya manusia merupakan kunci dari keberhasilan suatu instansi atau perusahaan karena sumber daya manusia pada suatu instansi memiliki nilai yang tinggi disebabkan oleh kemampuan, pengetahuan, dan keterampilan. Terkait dengan penyusunan laporan keuangan daerah yang sesuai dengan PSAP, maka perlu diperhatikan kualitas sumber daya manusia yang terlibat dengan penyusunan laporan keuangan pemerintah daerah, seperti pemahaman akan PSAP. Pemahaman terhadap SAP ini diperlukan agar hasil pekerjaan, dalam hal ini kualitas laporan audit

\section{Pengaruh Integritas auditor Terhadap Kualitas laporan audit di Inspektorat Daerah Provinsi Gorontalo}

Integritas merupakan kepatuhan

tanpa kompromi untuk kode nilai-nilai moral, dan menghindari penipuan, kemanfaatan, kepalsuan, atau kedangkalan apapun. Pentingnya integritas berasal dari ide bahwa profesi adalah "panggilan" dan membutuhkan profesional untuk fokus pada gagasan bahwa mereka melakukan pelayanan publik. Integritas mempertahankan standar prestasi yang tinggi dan melakukan kompetensi yang berarti memiliki kecerdasan, pendidikan, dan pelatihan untuk dapat nilai tambah melalui kinerja. Hal ini dikuatkan oleh pernyataan dari Sulila (2019) bahwa integritas merupakan faktor lain yang krusial dampaknya bagi peningkatan efektivitas pengelolaan keuangan pada suatu daerah. Hal ini menunjukan bahwa integritas pada auditor akan memberikan dampak baik bagi kinerja auditor terutama dalam peningkatan kualitas audit.

Hasil pengujian regresi khususnya untuk rumusan hipotesis kedua menunjukan bahwa nilai $t_{\text {hitung }}$ yang diperoleh lebih kecil dari nilai $t_{\text {tabel }}$. Nilai signifikansi Integritas auditor lebih besar dari nilai probabilitas 0,05 , atau nilai $(0,000<0,05)$. Sehingga dengan demikian dapat disimpulkan bahwa Integritas auditor berpengaruh positif dan signifikan terhadap Kualitas laporan audit di Inspektorat Daerah Provinsi Gorontalo. Koefisien dari regresi untuk pengujian hipotesis kedua yakni positif. Nilai t positif menunjukkan bahwa adanya hubungan yang searah antara integritas auditor dengan kualitas laporan audit di Inspektorat Daerah Provinsi Gorontalo. Artinya semakin baik integritas auditor dalam menjalankan tugas yang diamanahkan terhadapnya maka akan menunjang kualitas laporan audit di Inspektorat Daerah Provinsi Gorontalo untuk terus mengalami peningkatan.

Melalui hasil analisis ini maka pentingnya komitmen auditor perlu untuk ditingkatkan yang harus dilakukan dengan 2 
cara yakni melalui peran auditor itu sendiri dengan mengikuti berbagai kegiatan yang dapat meningkatkan kecerdasan emosional dan kecerdasan spiritualnya sehingga dapat menumbuhkan suatu sikap dan perilaku dalam pemeriksaan dan pengawasan peemrintahan yang sesuai dengan kode etik auditor internal dan kode etik sebagai manusia yang taat terhadap aturan dalam menjalankan sebuah amanah. Kemudian penting pula bagi pimpinan baik itu inspektur maupun pimpinan (kepala daerah) untuk melakukan penguatan pada kompetensi dan komitmen dari auditor agar dapat bertugas dengan baik sesuai dengan ketetapan yang diatur dalam perundangundangan untuk kegiatan audit internal. Aspek pimpinan merupakan hal yang krusial sebagaimana menurut Abdussamad (2017) bahwa fungsi suatu kepemimpinan akan mendorong bawahan menjadi lebih baik atau berintegritas untuk mencapai hasil kerja yang optimal.

Hasil penelitian yang menemukan terdapat pengaruh positif dan signifikan integritas auditor terhadap kualitas laporan audit di Inspektorat Daerah Provinsi Gorontalo sejalan dan mendukung penelitian yang pernah dilakukan oleh Ayuningtyas dan Pamudji (2012) yang menemukan bahwa Pengalaman audit tidak mempunyai pengaruh yang signifikan terhadap kualitas hasil audit. Independensi tidak mempunyai pengaruh yang signifikan terhadap kualitas hasil audit. Obyektifitas mempunyai pengaruh yang signifikan terhadap kualitas hasil audit. Integritas mempunyai pengaruh yang signifikan terhadap kualitas hasil audit. Kompetensi mempunyai pengaruh yang signifikan terhadap kualitas hasil audit. Integritas dapat menerima kesalahan yang tidak disengaja dan perbedaan pendapat yang jujur, tetapi tidak dapat menerima kecurangan prinsip. Dengan integritas yang tinggi, maka auditor dapat meningkatkan kualitas hasil pemeriksaannya

\section{Pengaruh Pemahaman pengelolaan aset tetap dan Integritas auditor Secara Simultan Terhadap Kualitas laporan audit di Inspektorat Daerah Provinsi Gorontalo}

Profesi auditor dalam menjalankan tugasnya selalu di dukung oleh beberapa faktor yang salah satunya integritas, profesionalisme audit, time budget pressure dan skeptisisme profesional. Faktor-faktor tersebut harus dimiliki seorang auditor dalam melaksanakan tugas audit. Kualitas audit menjadi salah satu indikator dari keberhasilan peemeriksaan dimana hal ini menjadi evaluasi bagi pemerintah. Sulila (2019) mengungkapkan bahwa kriteria evaluasi juga digunakan untuk meneliti data. Evaluasi program, kriteria berfungsi sebagai tolok ukur pencapaian suatu program sesuai dengan indikator yang ditetapkan. dalam hal ini evaluasi dilakukan oleh audiutor atas tata kelola administrasi dan juga keuangan daerah. Seluruh aspek ini telah diupayakan 
dengan optimal oleh auditor di Inspektorat daerah Provinsi Gorontalo.

Hasil pengujian regresi khususnya untuk rumusan hipotesis ketiga menunjukan bahwa Pemahaman pengelolaan aset tetap dan Integritas auditor) secara bersama-sama berpengaruh positif dan signifikan terhadap variabel terikat (Kualitas laporan audit di Inspektorat Daerah Provinsi Gorontalo dengan nilai determinan sebesar $72,00 \%$ sedangkan sisanya sebesar $28,00 \%$ dapat dijelaskan oleh variabel lain seperti variabel obyektivitas, tekanan waktu audit, komitmen organisasi, loyalitas kerja, perilaku disfungsional dan bimbingan teknis terkait dengan pemeriksaan yang intens dan rutin. Jika auditor semakin paham mengenai pengelolaan aset yang kemudian ditunjang dengan komitmen untuk selalu menjaga integritas maka akan membuat laporan audit dari auditor di Inspektorat Daerah Provinsi Gorontalo semakin berkualitas.

Kualitas audit sebagai kemungkinan bahwa auditor akan menemukan dan melaporkan pelanggaran dalam sistem akuntansi klien. Semua pelanggaran tergantung kepada dorongan auditor untuk mengungkapkan pelanggaran tersebut. Pengetahuan merupakan tingkat pemahaman auditor terhadap sebuah pekerjaan, secara konseptual atau teoritis. Selian itu, integritas sebagai mutu, sifat, atau keadaan yang menunjukkan kesatuan yang utuh, dimilikinya sifat jujur, kerasnya upaya, serta kompetensi yang memadai. Hal yang sama juga dinyatakan oleh Sulila (2019) bahwa tata kelola pemerintahan dapat dioptimalkan mellaui adanya sumber daya yang baik dalam hal ini pemahaman seorang auditor dan juga adanya sikap pelaksana yang baik yang dalam hal ini sikap integritas dari auditor.

Sementara itu hasil secara parsial ditemukan bahwa nilai koefisien determinasi yang hasilnya sebesar 0,626. Sehingga sebesar $62,60 \%$ kemampuan dari variabel pemahaman pengelolaan aset tetap dalam mempengaruhi kualitas laporan audit di Inspektorat Daerah Provinsi Gorontalo. Kemudian nilai koefisien determinasi yang hasilnya sebesar 0,661. Sehingga sebesar $66,10 \%$ kemampuan dari variabel integritas auditor dalam mempengaruhi kualitas laporan audit di Inspektorat Daerah Provinsi Gorontalo. Variabel integritas auditor yang paling signifikan karena adanya kecenderungan auditor yang merasa bahwa suatu pekerjaan yang dilakukan dengan sikap integritas maka akan semakin berkualitas seiring dengan adanya peningkatan pemahaman sebagai bagian dari adanya pengalaman melakukan pemeriksaan secara berintegritas.

Hal ini sesuai pendapat dari Mabruri dan Winarna (2010) menyatakan bahwa kualitas audit dapat dicapai jika auditor memiliki integritas yang baik dan hasil penelitiannya menemukan bahwa integritas 
berpengaruh terhadap kualitas audit. Auditor sebagai ujung tombak pelaksanaan tugas audit harus senantiasa meningkatkan pengetahuan yang telah dimiliki agar penerapan pengetahuan dapat maksimal dalam praktiknya. Auditor sebagai ujung tombak pelaksanaan tugas audit harus senantiasa meningkatkan pengetahuan yang telah dimiliki agar penerapan pengetahuan dapat maksimal dalam praktiknya.

\section{SIMPULAN}

Berdasarkan hasil penelitian dan pembahasan, maka dapat dikemukakan simpulan penelitian sebagai berikut:

1. Pemahaman pengelolaan aset tetap berpengaruh positif dan signifikan terhadap kualitas laporan audit di Inspektorat Daerah Provinsi Gorontalo dengan tingkat pengaruh sebesar $62,60 \%$. Semakin baik pemahaman auditor atas pengelolaan aset tetap maka laporan audit Inspektorat Daerah Provinsi Gorontalo akan semakin berkualitas.

2. Integritas auditor berpengaruh positif dan signifikan terhadap Kualitas laporan audit di Inspektorat Daerah Provinsi Gorontalo dengan tingkat pengaruh sebesar $66,10 \%$. Semakin baik integritas auditor dalam menjalankan tugas yang diamanahkan terhadapnya maka akan menunjang kualitas laporan audit di Inspektorat Daerah Provinsi Gorontalo untuk terus mengalami peningkatan.
3. Pemahaman pengelolaan aset tetap dan Integritas auditor) secara simultan berpengaruh positif dan signifikan terhadap variabel terikat (Kualitas laporan audit di Inspektorat Daerah Provinsi Gorontalo dengan nilai determinan sebesar 72,00\% sedangkan sisanya sebesar $28,00 \%$ dapat dijelaskan oleh variabel lain seperti variabel obyektivitas, tekanan waktu audit, komitmen organisasi, loyalitas kerja, perilaku disfungsional dan bimbingan teknis terkait dengan pemeriksaan yang intens dan rutin.

\section{SARAN}

Berdasarkan simpulan penelitian, maka peneliti memberikan saran sebagai berikut:

1. Pentingnya auditor di Inspektorat Daerah Provinsi Gorontalo untuk terus mengembangkan kemampuan dan pemahamannya terkait dengan pemeriksaan dan pengelolaan aset di lingkungan pemerintahan agar tidak terjadi ketidakwajaran dalam pengelolaan Barang Milik Negara (BMN).

2. Pentingnya auditor mengikuti berbagai kegiatan yang dapat meningkatkan kecerdasan emosional dan kecerdasan spiritualnya. Kemudian penting pula bagi pimpinan baik itu inspektur maupun pimpinan (kepala daerah) untuk 
melakukan penguatan pada kompetensi dan komitmen dari auditor.

3. Perlu adanya monitoring dan evaluasi serta tindak lanjut terhadap temuantemuan hasil BPK kemudian memfokuskan pada tahun berikutnya pada temuan tersebut. Kemudian menjadikan tekanan anggaran waktu menjadi motivasi bagi auditor dalam menyelesaikan pekerjaan sesuai dengan waktu yang telah ditetapkan.

\section{DAFTAR PUSTAKA}

Abdussamad, Zuchri. 2014. Kompetensi Aparat Dalam Pelayanan Publik. Gorontalo: Deepublish.

Abdussamad, Zuchri. 2017. The role of leadership functions and organizational culture improving employee performance. Journal Management and Business Review 1(1) 2017, 24-29

Agoes, Sukrisno. 2012. Auditing Petunjuk Praktis Pemeriksaan Akuntan Oleh. Akuntan Publik", Jilid 1, Edisi Keempat, Jakarta: Penerbit Salemba Empat

Ayuningtyas, Harvita Yulian dan Sugeng Pamudji. 2012. "Pengaruh Pengalaman Kerja, Independensi, Obyektifitas, Integritas Dan Kompetensi Terhadap Kualitas Hasil Audit" Diponegoro Journal Of Accounting, Vol. 1 No.2

Mabruri dan Winarna. 2010. Analisis FaktorFaktor Yang Mempengaruhi Kualitas Hasil Audit di Lingkungan Pemerintah Daerah". SNA XIII Purwokerto
Nikijuluw, Misye; Jantje Tinangon dan Heince Wokas. 2017. Analisis Implementasi Psap No.07 Tentang Akuntansi Aset Tetap Pada Balai Penyantunan Lanjut Usia "Senja Cerah". Jurnal Riset Akuntansi Going Concern 12(1), 2017, 42-47

Sari, dkk. 2014. Pengaruh Pemahaman Standar Akuntansi Pemerintahan (SAP) dan Pemanfaatan Sistem Informasi Akuntansi Keuangan Daerah Terhadap Kualitas Laporan Keuangan Pemerintah Daerah (Studi Kasus Pada Dinas-Dinas di Pemerintah Kabupaten Jembrana). Jurnal Jurusan Akuntansi Program S1 (Volume 2 No. 1 Tahun 2014) September-Desember 2011.

Sukriah, Ika, dkk. 2009. Jurnal. "Pengaruh Pengalaman Kerja, Independensi, Objektivitas, Integritas, dan Kompetensi terhadap Kualitas Hasil Pemeriksaan". Simposium Nasional Akuntansi XII, Palembang

Sulila, Ismet. 2018. An Implementation of Restaurant Tax Policy to Increase Local Revenues in Gorontalo City. Jurnal MIMBAR, Vol.34 No 2nd (December) 2018 page 406-413. Print ISSN: 0215-8175; Online ISSN: $\quad 2303-2499 . \quad$ DOI: http://dx.doi.org/10.29313/mimbar.v $\underline{34 \mathrm{i} 2.3683 .406-413}$

Sulila, Ismet. 2019. An Analysis of the Effectiveness of Allocation of Village Fund Policy Implementation and Its Determining Factors in Gorontalo Regency. Jurnal Ilmiah Ilmu Administrasi Publik: Jurnal Pemikiran dan Penelitian Administrasi Publik Volume 9 Number 2, July- December 2019. Page 67-78 p-ISSN: 2086-6364, eISSN: 2549-7499. DOI: https://doi.org/10.26858/jiap.v9i2.1 $\underline{0947}$ 
Sulila, Ismet. 2019. Regional Financial Public Services Evaluation Based on Regional Budget and Expenditure. Jurnal Sosial dan Pembangunan MIMBAR. Volume 35 Nomor 2. Page 295-305 Print ISSN: 0215-8175; Online ISSN: 2303-2499.

DOI: https://doi.org/10.29313/mimbar.v3 $\underline{5 \mathrm{i} 2.4674}$

Sulila, Ismet. 2019. The Effect Of Effectiveness of Advertising Tax Collection And Material Compliance With Regional Revenue Of Gorontalo. Jurnal Ilmu Administrasi (JIA) Media Pengembangan Ilmu dan Praktek Administrasi. Page 179-193. Print ISSN 1829 - 8974 e-ISSN 26142597. DOI: https://doi.org/10.31113/jia.v16i2.4 99

Syamsudin, Lukman. 2004. Manajemen Keuangan Perusahaan. Cetakan ke-8. Penerbit PT Raja Grafindo Persada. Jakarta.

Tugiman, Hiro. 2006. Standar profesional audit internal. Yogyakarta : Kanisius. 